\title{
Non-Carious Cervical Lesions and risk factors in Brazilian athletes: a cross sectional
}

\section{study}

\section{Lesões cervicais não cariosas e fatores de risco em atletas brasileiros: um estudo transversal}

Lesiones cervicales no cariosas y factores de riesgo en deportistas brasileños: estudio transversal

\begin{abstract}
Objective: This study aimed to evaluate the prevalence of Noncarious Cervical Lesions (NCCL), Cervical Dentin Hypersensitivity (CDH) and Gingival Recession (GR) and their associated risk factors in athletes. Methodology: A questionnaire was used to obtain basic information. An evaluator clinically examined all subjects. Statistical analysis was performed using Poisson multiple regression with robust variance, and the prevalence ratio and confidence intervals (95\%) were calculated. Results: The final sample consisted of 264 athletes of different sports (7285 teeth). The present study found that the type of sport and weekly training time are important factors. Athlete's ages ranged from 17 to 46 years (mean: 20.33 years). Majority of the athletes were males $(90.46 \%)$. The teeth most affected by NCCL were the first upper premolars $(29.35 \%)$, and the prevalence of NCCL increased with age. The prevalence of NCCL, CDH, and GR was $17.42 \%, 35.35 \%$, and $59.09 \%$, respectively. The linear regression shows that the most important risk factor(s) for NCCL was age, training hours, stress, excessive brushing force and orthodontic appliance; for $\mathrm{CDH}$ were age, education, type of sport, training hours and acid diet; and for GR were age, income, education, type of sport and excessive teeth brushing. Conclusion: It must be understood that the presence of all elements are factors capable of destabilizing the athlete's daily life. Athletes have risk factors that are closely related to the onset and progression of the disease. It is necessary that the dentist knows prevention and minimization measures.
\end{abstract}

Keywords: Cross-sectional studies; Risk factors; Sport dentistry; Athletes; Dentin sensitivity; Tooth wear.

\section{Resumo}

Objetivo: Este estudo teve como objetivo avaliar a prevalência de Lesões Cervicais Não Cariosas (NCCL), Hipersensibilidade Dentinária Cervical (HDC), Recessão Gengival (RG) e seus fatores de risco associados em atletas. Metodologia: Um questionário foi usado para obter informações básicas. Um avaliador examinou clinicamente todos os indivíduos. A análise estatística foi realizada por meio de regressão múltipla de Poisson, calculando-se a razão de prevalência e os intervalos de confiança (95\%). Resultados: A amostra final foi composta por 264 atletas de diferentes modalidades (7285 dentes). A idade dos atletas variou de 17 a 46 anos (média: 20,33 anos). A maioria dos atletas era do gênero masculino $(90,46 \%)$. Os dentes mais afetados pelo NCCL foram os primeiros pré-molares superiores $(29,35 \%)$, e a prevalência de NCCL aumentou com a idade. A CDH estava presente no incisivo central inferior $(20,13 \%)$ e $56,52 \%$ dos atletas tinham de um a dois dentes com CDH. A prevalência de NCCL, CDH e GR foi de 
$17,42 \%, 35,35 \%$ e 59,09\%, respectivamente. A regressão linear mostrou que os fatores de risco mais importantes para NCCL foram idade, horas de treinamento, estresse, força excessiva de escovação e aparelho ortodôntico; para CDH foram idade, escolaridade, tipo de esporte, horas de treinamento e dieta ácida; e para GR foram idade, renda, escolaridade, tipo de esporte e escovação excessiva dos dentes. Conclusão: Deve-se entender que a presença de todos os elementos são fatores capazes de desestabilizar o dia a dia do atleta. Os atletas apresentam fatores de risco intimamente relacionados ao início e à progressão da doença. É necessário que o dentista conheça as medidas de prevenção e minimização dos danos.

Palavras-chave: Estudos transversais; Fatores de risco; Odontologia do esporte; Atletas; Sensibilidade da dentina; Desgaste dentário.

\section{Resumen}

Objetivo: Este estudio tuvo como objetivo evaluar la prevalencia de lesiones cervicales no cariosas (NCCL), hipersensibilidad dentinaria cervical (HDC) y recesión gingival (RG) y sus factores de riesgo asociados en deportistas. Metodología: se utilizó un cuestionario para obtener información básica. Un evaluador examinó clínicamente a todos los sujetos. El análisis estadístico se realizó mediante regresión múltiple de Poisson con varianza robusta, calculando la razón de prevalencia y los intervalos de confianza (95\%). Resultados: La muestra final estuvo constituida por 264 deportistas de diferentes deportes (7285 dientes). La edad de los deportistas osciló entre los 17 y los 46 años (media: 20,33 años). La mayoría de los deportistas eran hombres (90,46\%). Los dientes más afectados por NCCL fueron los primeros premolares superiores $(29,35 \%)$, y la prevalencia de NCCL aumentó con la edad. CDH estaba presente en el incisivo central mandibular $(20,13 \%)$ y el $56,52 \%$ de los atletas tenía uno o dos dientes con CDH. La prevalencia de NCCL, CDH y GR fue del 17,42\%, 35,35\% y 59,09\%, respectivamente. La regresión lineal muestra que los factores de riesgo más importantes para NCCL fueron la edad, las horas de entrenamiento, el estrés, la fuerza excesiva de cepillado y el aparato de ortodoncia; para CDH fueron edad, educación, tipo de deporte, horas de entrenamiento y dieta ácida; y para RG fueron la edad, los ingresos, la educación, el tipo de deporte y el cepillado de dientes excesivo. Conclusión: Debe entenderse que la presencia de todos los elementos son factores capaces de desestabilizar la vida diaria del deportista. Los deportistas tienen factores de riesgo que están estrechamente relacionados con la aparición y progresión de la enfermedad. Es necesario que el dentista conozca las medidas para prevenir y minimizar los daños.

Palabras clave: Estudios transversales; Factores de riesgo; Odontología deportiva; Atletas; Sensibilidad dentinaria; Desgaste dental.

\section{Introduction}

Dentists who work in the sports field should evaluate the oral health of athletes in order to detect alterations and pathologies that could compromise their athletic performance during training and competitions.(Gallagher et al., 2018; Needleman et al., 2013; Soares et al., 2014; Souza et al., n.d.) The literature comprises of studies that evaluated the general oral health of athletes. (Bryant et al., 2011; Frese et al., 2015; Gallagher et al., 2018; Mathew et al., 2002; Ian Needleman et al., 2016; Sirimaharaj et al., 2002) However, few studies objectively analyzed the presence of non-carious cervical lesion (NCCL) or dentin hypersensitivity (CDH) and gingival recession (GR).

NCCLs are characterized by the loss of tooth structure at the cement-enamel junction, not related to bacteriological processes. NCCLs are common, irreversible, and area growing concern for dentists and researchers. The etiology and progression is multifactorial and involves complex interactions associated with the concentration of cervical stress (abfraction), mechanical friction, and the biocorrosion (endogenous and exogenous acids). (Grippo et al., 2012; PV Soares \& Grippo, 2017) As a consequence, NCCLs have been associated with other conditions such as cervical dentin hypersensitivity (CDH) and gingival recession (GR). (Grippo et al., 2012; PV Soares \& Grippo, 2017; Teixeira et al., 2020; Yoshizaki et al., 2017)

Pain associated with $\mathrm{CDH}$ is characterized as short and acute, arising when the dentin is exposed to external agents (chemical, thermal, tactile, evaporative or osmotic). (Canadian Advisory Board on Dentin Hypersensitivity, 2003; DG, 2017; LF et al., 2020; West et al., 2013) It is a very uncomfortable feeling and often impacts the patients' daily routine (eating, drinking, breathing, brushing teeth). The treatment of $\mathrm{CDH}$ is based on the control of etiological factors, such as adjustments in occlusion and disocclusion, orientation/adaptation of diet and brushing instructions (type of brush, toothpaste, brushing strength) (Favaro Zeola et al., 2019; Galvão et al., 2019; LF et al., 2020; Nascimento et al., 2020; Soares \& Grippo, 2017) 
The routine of athletes is closely associated with the etiological factors of NCCL. For example, they spend hours in the gym performing exercises that often cause voluntary clenching. (Medeiros et al., 2020; PV Soares \& Grippo, 2017) Concomitantly, during exercise naturally there is a decrease in the rate of salivary flow and pH also decreases.(Broad \& Rye, n.d.; Frese et al., 2015; Mulic et al., 2012). Moreover, athletes generally present an acid diet that have low pH and therefore interfering the buffering capacity of oral saliva.(Broad \& Rye, n.d.; Gallagher et al., 2018; Moazzez et al., 2000; Ian Needleman et al., 2016; Tanabe et al., 2013)

Although NCCLs are common in dental practice (Borcic et al., 2005; Favaro Zeola et al., 2019; Medeiros et al., 2020; Teixeira et al., 2018; Yoshizaki et al., 2017), only one study was found with athletes.(Medeiros et al., 2020) Data on NCCLs could help identify specific factors and be used as a guide to implement preventive strategies. (Borcic et al., 2005; PV Soares $\&$ Grippo, 2017) Therefore, the objective of this study was to evaluate the prevalence of NCCL, CDH, GR and the risk factors in Brazilian athletes.

\section{Methodology}

\section{Study design}

This study is a cross-sectional, single-center study conducted from June 2015 to June 2016. The protocol for this study was approved by the Ethics Committee of the School of Dentistry of University of São Paulo (process \#981.095). The athletes were selected from various sports. For individuals under 18 years, prior authorization was requested from those legally responsible for them. Inclusion criteria were had to be at least 17 years of age, good overall health and should be competing for state, Brazilian, South American, or world championships. Exclusion criteria included athletes with caries, dental prosthesis, previous tooth whitening, pregnant or breastfeeding and water sports athletes, who require a different training environment.

As there were no studies on the prevalence of these lesions in athletes, a pilot study was previously conducted, which provided prevalence data to enable sample size calculation. The calculated sample size was 276 , with a $95 \%$ confidence level, and a $5 \%$ margin of error $(\mathrm{p} \leq 0.05)$.

Initially, calibration was performed to train the examiner in the diagnosis of NCCL/CDH/GR/. An experienced researcher from the research group instructed the examiner on how to make the diagnosis on individuals who were not part of the final sample. The dentist has been trained to perform clinical evaluations to ensure consistency in the techniques, criteria, and research procedures used. The intra-examiner test resulted in a kappa of $80 \%$.

The purpose of the research was explained to the athletes, and they were then invited to participate. Written consent was obtained from all the athletes. A questionnaire containing personal characteristics and lifestyle associated with NCCLs, $\mathrm{CDH}$, GR (age, income, education level, diet acid, sport, training per week, acid diet, pain and cracking in the temporomandibular joint (TMJ), self-quiz questions such as "consider yourself a nervous person, gridding, clenching, biting objects, nail-biting, brushing with excessive force, the use of fixed appliance, and flossing) was used by the investigator to collect relevant information from each individual.

\section{Clinical evaluation}

Many clubs in Brazil do not have dental care offices. Due to issues with logistics, evaluations to identify lesions were performed with a common chair, good lighting illumination, wooden spatula, and compressed air (Air Duster-Implastec, Votorantim, SP, Brazil). No clinical instruments were used for evaluation. All teeth were dried with gauze before examination. The subjects were examined for the presence of Biofilm, GR, CDH, NCCL, wear facets, and malocclusion (open bite, deep bite, cross bite, end to end bite, prognathism); the absence of dental elements, canine guide and the quality of oral health. 
During the evaluation to detect lesions, any loss of hard tissue in the cervical region of the tooth not related to caries, was considered as NCCL. Particularly for minor lesions, the evaluation was based on a comparison with the morphology of the adjacent and contralateral teeth.(Bader et al., 1996)

For the evaluation of $\mathrm{CDH}$, an evaporative stimulus (controlled air blast) was used. The air jet was directed perpendicular to the cervical buccal surface of the tooth for two seconds at a distance of approximately $1 \mathrm{~cm}$. The adjacent teeth were protected with cotton and digital locking to avoid false-positive results. Patients were instructed to raise their hand if they felt any discomfort. Teeth with alterations were examined to determine if the alterations were due to GR or/and NCCL. The operator asked the athletes to quantify their pain using a Visual Analogue Scale (VAS), with 0 indicating no sensitivity and 10 indicating maximum sensitivity.

GR was also evaluated and classified as either present or absent. GR was considered when the tooth had a distance from the gingival margin to the cement-enamel union on the buccal surface.

\section{Patient and public involvement}

The athletes participating in the research were involved as knowledge intermediaries in all aspects of the research process. The Club members or those responsible for the athletes supported the planning, recruitment, data collection and dissemination of results to the sports community.

\section{Statistical analysis}

Data collected using the questionnaire and during clinical examinations were classified. A frequency distribution table was constructed and crosstabulation analysis was performed. Statistical analysis of the data was performed using the Poisson multiple regression model with a robust variance, and the prevalence ratio and respective confidence intervals (95\% CI) were calculated. Independent variables with $\mathrm{p}<0.05$ in the univariate model were inserted into the final multivariate model. The level of significance adopted was 5\%. The software Stata, version 14.0 (StataCorp LP, College Station, TX, USA), was used to perform all analyses.

\section{Results}

\section{Characteristics of the athletes}

Two hundred and sixty-four individuals (resulting in the evaluation of 7285 teeth) participated in the study and their general characteristics are shown in Table 1,2,3. The ages of the athletes ranged from 17 to 46 years (mean: 20.33 years), and the sports categories were soccer $(n=157)$, rugby/football $(n=47)$, volleyball/handball $(n=39)$, and others (taekwondo/jiu $\mathrm{jitsu} / \mathrm{mma} /$ rowing $)(\mathrm{n}=21)$. There were more males $(90.46 \%)$ than females $(9.55 \%)$.

\section{Characteristics of the NCCL/CDH/GR}

The teeth distribution for each condition evaluated in this study is presented in Figure 1. The prevalence of NCCL was $17.42 \%$. Of the individuals with NCCL, $73.91 \%$ had one to two teeth with NCCL, $17.39 \%$ had three to five teeth with NCCL, and $8.70 \%$ had more than five teeth with NCCL. The most affected teeth were the first upper premolars (29.35\%), first lower premolars (21.09\%), and second upper premolars (9.17\%). Of the individuals who had NCCL, 46.68\% also had CDH. Overall, the prevalence of $\mathrm{CDH}$ was $35.25 \%$ ( $\mathrm{n}=92)$, affecting mainly the lower central incisors $(20.13 \%)$ and first maxillary premolars (15.84\%). The main cause of severe CDH was GR (48.97\%). More than half of the athletes $(56.52 \%)$ had one to two teeth with $\mathrm{CDH}, 27.17 \%$ had three to five teeth with $\mathrm{CDH}$, and $17.39 \%$ had more than five teeth with $\mathrm{CDH}$. Regarding GR, 
$59.09 \%$ of athletes were affected, with the most affected teeth being the first lower premolars (19.97\%), followed by the first upper premolars $(19.61 \%)$.

Figure 1. Distribution of all teeth and their prevalence of GR/CDH/NCCL

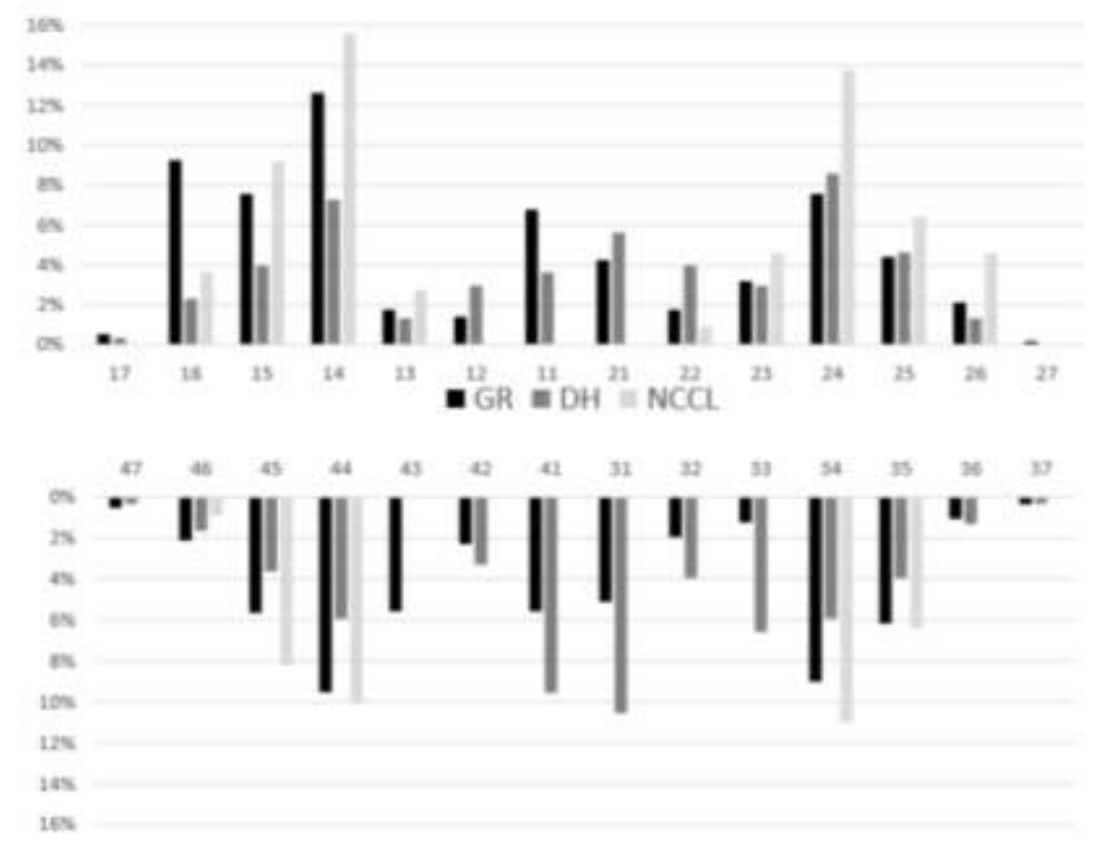

Source: Authors.

The frequency of NCCL, CDH, and RG according to different age groups is shown in Figure 2. The prevalence of NCCL increased with increasing age. GR was more prevalent in the group of athletes between the ages of 21 and 28 years, whereas $\mathrm{CDH}$ was more pronounced in the group of athletes who were more than 28 years old. The results also showed that $\mathrm{CDH}$ was significantly associated with GR in the group of athletes between the ages of 17 and 20 years and those between the ages of 21 and 28 years. On the other hand, NCCL, CDH, and GR were significantly associated in the group of athletes who were more than 28 years old (Figure 3).

Figure 2. Athlete's distribution per age with isolated incidence of NCCLs, CDH and GR.

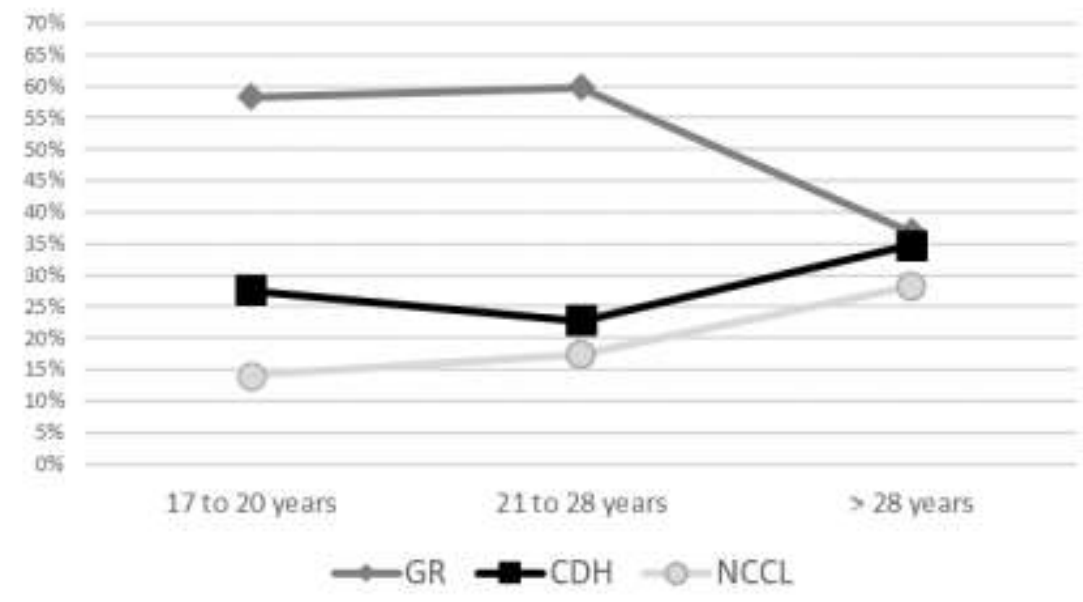

Source: Authors. 
Figure 3. Subject distribution per age with combined incidence of NCCL+CDH, NCCL+GR, GR+CDH, and $\mathrm{NCCL}+\mathrm{CDH}+\mathrm{GR}$.

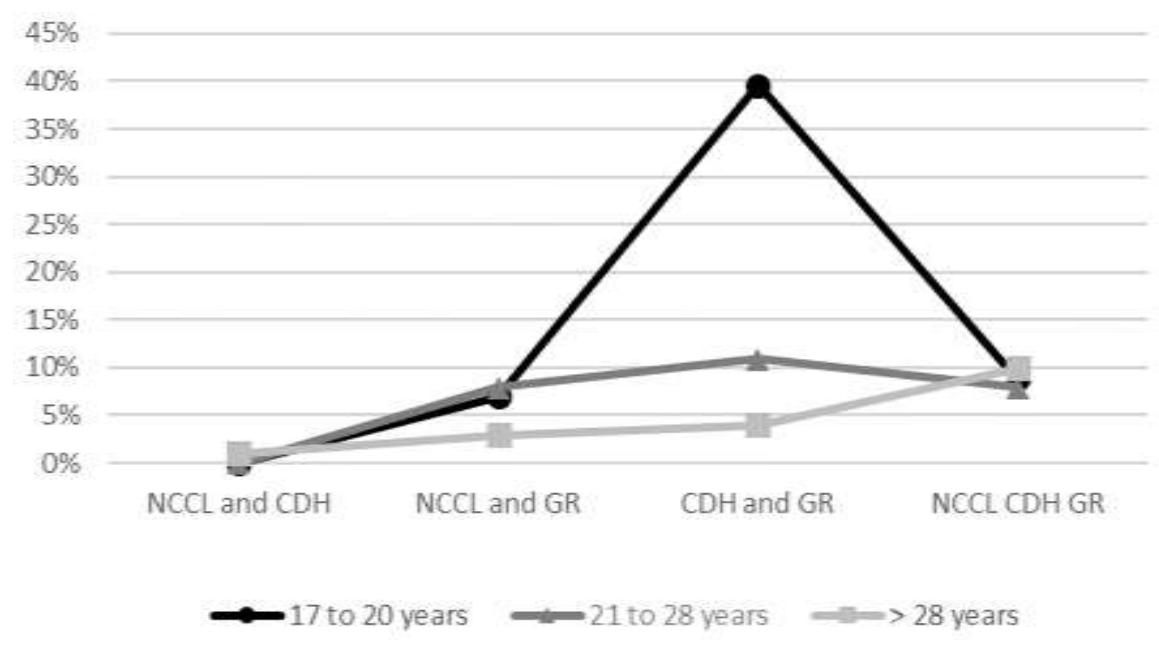

Source: Authors.

Figure 4 shows the prevalence of each lesion within each modality. Within all the modalities, the prevalence of GR was the highest in relation to CDH and NCCL. Taekwondo/jiujitsu/mma/rowing sports showed a greater presence of NCCL/CDH/GR when compared to other sports.

Figure 4. Prevalence distribution of NCCL/CDH/GR among sport.

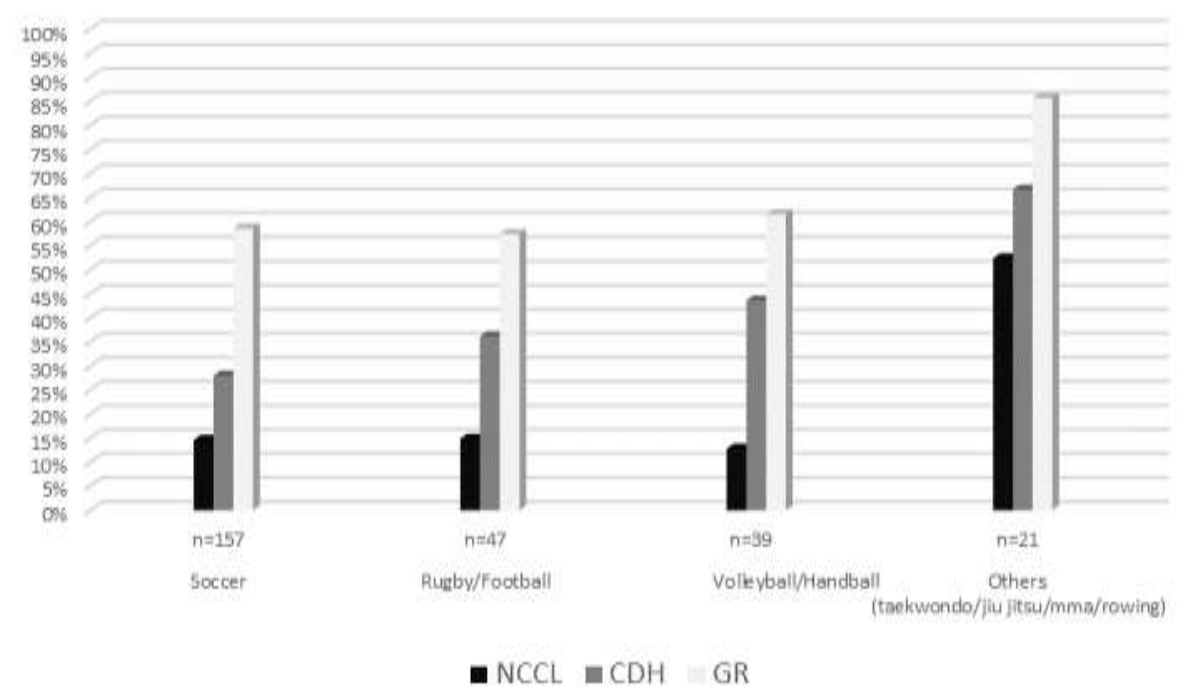

Source: Authors.

\section{Risk factor for NCCL/CDH/GR}

The results of the multiple multilevel Poisson analysis for the possible risk factors for NCCL, CDH, and GR are shown in Table 2. Non-significant variables in the univariate analysis were not included in the final multiple model. It is possible to observe that training more than 15 hours a week and brushing teeth with great force has an influence on the presence of NCCL, CDH and GR. 
Research, Society and Development, v. 10, n. 9, e57210917859, 2021

(CC BY 4.0) | ISSN 2525-3409 | DOI: http://dx.doi.org/10.33448/rsd-v10i9.17859

Table1. Bivariate analysis (Mann Whitney) between NCCL, CDH and GR and risk factors in overall sample.

\begin{tabular}{|c|c|c|c|c|c|c|c|c|c|c|c|c|}
\hline & \multicolumn{2}{|c|}{ NCCL } & \multirow[b]{2}{*}{$95 \% \mathrm{CI}$} & \multicolumn{3}{|c|}{$\mathrm{CDH}$} & \multicolumn{4}{|c|}{$G R$} & \multirow[b]{2}{*}{$95 \% \mathrm{CI}$} & \multirow[b]{2}{*}{$P$ value } \\
\hline & $\begin{array}{l}\text { Odds } \\
\text { ratio } \\
\end{array}$ & SE & & $P$ value & $\begin{array}{l}\text { Odds } \\
\text { ratio }\end{array}$ & SE & $95 \% \mathrm{CI}$ & $P$ value & $\begin{array}{l}\text { Odds } \\
\text { ratio } \\
\end{array}$ & SE & & \\
\hline \multicolumn{13}{|c|}{ Age (reference: 17 to 20 years) } \\
\hline 21 to 28 years & 5.46 & 0.79 & $4.10-7.27$ & $<0.001^{*}$ & 1.40 & 0.19 & $1.06-1.85$ & $0.015^{*}$ & 1.61 & 0.16 & $1.32-1.96$ & $<0.001^{*}$ \\
\hline$>29$ years & 6.28 & 1.14 & $4.40-8.97$ & $<0.001 *$ & 3.90 & 0.58 & $2.91-5.23$ & $<0.001 *$ & 4.12 & 0.47 & $3.29-5.16$ & $<0.001^{*}$ \\
\hline \multicolumn{13}{|c|}{ Income (reference: low) } \\
\hline Medium & 3.89 & 0.59 & $2.89-5.25$ & $<0.001^{*}$ & 0.85 & 0.13 & $0.62-1.17$ & 0.331 & 0.91 & 0.10 & $0.72-1.14$ & 0.445 \\
\hline High & 6.59 & 1.02 & $4.86-8.93$ & $<0.001^{*}$ & 1.37 & 0.22 & $0.99-1.90$ & 0.051 & 1.81 & 0.20 & $1.45-2.27$ & $<0.001^{*}$ \\
\hline \multicolumn{13}{|c|}{ Sport (reference: Soccer) } \\
\hline Football/rugby & 0.90 & 0.16 & $0.63-1.30$ & 0.607 & 1.30 & 0.23 & $0.92-1.85$ & 0.132 & 1.11 & 0.13 & $0.87-1.41$ & 0.368 \\
\hline Volleyball/Handball & 0.58 & 0.13 & $0.36-0.93$ & $0.024^{*}$ & 2.34 & 0.37 & $1.72-3.20$ & $<0.001 *$ & 1.51 & 0.18 & $1.19-1.91$ & $<0.001^{*}$ \\
\hline Others & 4.10 & 0.64 & $3.02-5.57$ & $<0.001^{*}$ & 6.64 & 1.00 & $4.93-8.94$ & $<0.001^{*}$ & 3.62 & 0.44 & $2.85-4.61$ & $<0.001^{*}$ \\
\hline \multicolumn{13}{|c|}{ Training hours (reference:up } \\
\hline \multicolumn{13}{|l|}{ to 15 hours) } \\
\hline$>15$ hours & 2.16 & 0.27 & $1.68-2.77$ & $<0.001^{*}$ & 1.42 & 0.16 & $1.13-1.78$ & $0.002^{*}$ & 1.23 & 0.10 & $1.04-1.45$ & $0.015^{*}$ \\
\hline \multicolumn{13}{|c|}{ Acidic diet (reference: no) } \\
\hline Yes & 0.70 & 0.09 & $0.55-0.91$ & $0.008^{*}$ & 1.41 & 0.16 & $1.12-1.78$ & $0.003 *$ & 1.12 & 0.09 & $0.95-1.33$ & 0.153 \\
\hline \multicolumn{13}{|c|}{ Pain in the TMJ (reference: } \\
\hline \multicolumn{13}{|l|}{ no) } \\
\hline Yes & 5.73 & 0.80 & $4.35-7.54$ & $<0.001 *$ & 1.61 & 0.29 & $1.12-2.29$ & $0.008^{*}$ & 1.39 & 0.19 & $1.05-1.83$ & $0.019 *$ \\
\hline \multicolumn{13}{|c|}{ Cracking (reference: no) } \\
\hline Yes & 1.44 & 0.19 & $1.11-1.88$ & $0.006^{*}$ & 1.16 & 0.15 & $0.89-1.50$ & 0.257 & 1.10 & 0.10 & $0.91-1.34$ & 0.298 \\
\hline \multicolumn{13}{|l|}{ Stress (reference: no) } \\
\hline Yes & 2.70 & 0.37 & $2.06-3.55$ & $<0.001^{*}$ & 1.19 & 0.13 & $0.94-1.49$ & 0.131 & 0.68 & 0.05 & $0.58-0.81$ & $<0.001^{*}$ \\
\hline \multicolumn{13}{|c|}{ Gridding (reference: no) } \\
\hline Yes & 2.39 & 0.31 & $1.85-3.09$ & $<0.001^{*}$ & 1.13 & 0.16 & $0.86-1.49$ & 0.366 & 1.21 & 012 & $0.99-1.47$ & 0.061 \\
\hline Clenching (reference: & & & & & & & & & & & & \\
\hline Yes & 0.56 & 0.08 & $0.41-0.75$ & $<0.001^{*}$ & 0.99 & 0.12 & $0.78-1.26$ & 0.978 & 1.00 & 0.09 & $0.84-1.20$ & 0.936 \\
\hline Biting Objects (refere & & & & & & & & & & & & \\
\hline Yes & 0.78 & 0.10 & $0.60-1.02$ & 0.071 & 1.06 & 0.12 & $0.84-1.34$ & 0.589 & 0.83 & 0.07 & $0.70-0.99$ & $0.046^{*}$ \\
\hline Nail-Biting (reference & & & & & & & & & & & & \\
\hline Yes & 0.90 & 0.11 & $0.70-1.15$ & 0.415 & 1.06 & 0.12 & $0.84-1.33$ & 0.615 & 0.76 & 0.06 & $0.65-0.91$ & $0.002 *$ \\
\hline Excessive brushing fo & & & & & & & & & & & & \\
\hline (reference:no) & & & & & & & & & & & & \\
\hline Yes & 2.75 & 0.39 & $2.08-3.64$ & $<0.001^{*}$ & 1.30 & 0.15 & $1.03-1.64$ & $0.024 *$ & 1.35 & 0.11 & $1.14-1.60$ & $<0.001^{*}$ \\
\hline Biofilm (reference: no & & & & & & & & & & & & \\
\hline Yes & 0.95 & 0.11 & $0.74-1.21$ & 0.701 & 0.95 & 0.11 & $0.75-1.19$ & 0.667 & 0.83 & 0.07 & $0.70-0.98$ & $0.030 *$ \\
\hline Dental absence (refere & & & & & & & & & & & & \\
\hline Yes & 1.20 & 0.17 & $0.89-1.60$ & 0.217 & 1.36 & 0.18 & $1.05-1.78$ & $0.020^{*}$ & 1.69 & 0.16 & $1.40-2.04$ & $<0.001^{*}$ \\
\hline Orthodontic applianc & & & & & & & & & & & & \\
\hline (reference: no) & & & & & & & & & & & & \\
\hline Yes & 2.49 & 0.32 & $1.92-3.22$ & $<0.001^{*}$ & 0.99 & 0.11 & $0.79-1.25$ & 0.976 & 1.04 & 0.08 & $0.88-1.23$ & 0.617 \\
\hline Malocclusion (referen & & & & & & & & & & & & \\
\hline Yes & 0.29 & 0.04 & $0.22-0.40$ & $<0.001^{*}$ & 0.69 & 0.08 & $0.54-0.87$ & $0.002 *$ & 0.92 & 0.07 & $0.78-1.09$ & 0.390 \\
\hline Canine Guide Right & & & & & & & & & & & & \\
\hline (reference: no) & & & & & & & & & & & & \\
\hline Yes & 0.55 & 0.09 & $0.40-0.76$ & $<0.001^{*}$ & 1.08 & 0.13 & $0.84-1.39$ & 0.538 & 1.16 & 0.10 & $0.96-1.39$ & 0.108 \\
\hline Canine Guide Left ( $r$ & & & & & & & & & & & & \\
\hline no) & & & & & & & & & & & & \\
\hline Yes & 0.19 & 0.04 & $0.12-0.29$ & $<0.001^{*}$ & 0.59 & 0.08 & $0.45-0.78$ & $<0.001^{*}$ & 0.87 & 0.08 & $0.72-1.05$ & 0.161 \\
\hline Wear facet (reference & & & & & & & & & & & & \\
\hline Yes & 1.73 & 0.22 & $1.35-2.22$ & $<0.001^{*}$ & 1.19 & 0.13 & $0.94-1.49$ & 0.134 & 1.40 & 0.12 & $1.18-1.65$ & $<0.001 *$ \\
\hline
\end{tabular}

$\mathrm{SE}=$ Standard Error.

$*$ = significant statistic difference.

Source: Authors. 


\section{Discussion}

\section{Key findings}

The present study is the first to investigate the prevalence of NCCL, CDH, and GR in athletes and found that the type of sport and weekly training time are important factors in the onset these lesions. The results make it possible to raise some questions and could guide and help clinicians to prevent and manage these alterations in athletes.

\section{Prevalence data e comparison with previous studies}

Recent data from the literature shows a prevalence of NCCL ranging from 5\% to $88.1 \%$ in the general population. (Bartlett \& Shah, 2006; Teixeira et al., 2018; Yoshizaki et al., 2017; Zuza et al., 2019) This high degree of discrepancy is due to the differences in study designs and instruments of analysis used. There is only one study with athletes that found a $39.5 \%$ prevalence of NCCL (with an average of 27 years) and in this present study, we found a number of $17.42 \%$ (mean age 20.33 years).

The tooth most affected by NCCL and GR was the upper premolar, followed by the lower premolar, which is consistent with the results of other studies.(Medeiros et al., 2020; Que et al., 2013; Teixeira et al., 2018; Yang et al., 2016; Zuza et al., 2019) The most commonly found tooth with CDH was the incisors, followed by the premolars, which will encounter some studies with non-athletes. (Alcântara et al., 2018; Silva et al., 2019) Although others indicate that the premolar is the most affected tooth.(Que et al., 2013; Wang et al., 2012; Yoshizaki et al., 2017) The high prevalence in premolars can be explained using the concepts of biomechanics. The cervical constriction in premolars provides a tensile stress in this region that have a thinner buccal bone plate which leads to greater flexion of the tooth in the vestibular face, making them more susceptible to lesion formation.(Brandini, Pedrini, et al., 2012; P V Soares et al., 2014)

A number of studies have explored the relationship between NCCL and its risk factors in the general population.(Brandini, Trevisan, et al., 2012; Que et al., 2013; Teixeira et al., 2018; Yoshizaki et al., 2017; Zuza et al., 2019) Multivariate regression analysis revealed a significant association between NCCLs and age. In our study, the highest incidence of NCCL was found among athletes who were more than 28 years old $(28.6 \%, \mathrm{p}=0.015)$, followed by those between the ages of 21 and 28 years (17.39\%), and those between the ages of 17 and 20 years $(14.10 \%)$. This finding is consistent with the findings of previous studies which reported that the frequency and magnitude of NCCLs increase with age, possibly due to prolonged exposure to causative factors.(Borcic et al., 2004; Que et al., 2013)

A significant association between NCCL/CDH/GR and individuals who train more than 15 hours a week was found, which corroborates with other studies. (Antunes et al., 2017; Medeiros et al., 2020) In order for athletes to perform during physical exercise, sports nutrition is extremely important and as it is known that diet is considered a biocorrosive etiological factor of exogenous origin (fruits and juices, carbonated soft drinks, acidic sports drinks, alcoholic beverages, some medications and supplements). The diets of athletes are individualized and dependent on the type, duration, frequency, and intensity of their training and usually, includes acidic foods. (Broad \& Rye, n.d.; Rogerson, 2017; Sirimaharaj et al., 2002) The caloric intake of macro and micronutrients is necessary to collaborate in the athlete's performance.(F et al., 2007) Nutritional habits and foods are of interest to sports, especially considering their effects on sports performance, but also as an important factor in the possible onset or progression of CDH and NCCL. In the present study, there was weak significant association among $\mathrm{CDH}$ and acid diet, however, other studies reported a correlation between acid diet and tooth wear.(West et al., 2013; Yoshizaki et al., 2017)

Temporomandibular disorder (TMD) is a clinical problem with a multifactorial etiology that involves the masticatory muscles and the temporomandibular joints (TMJ), individually or together. The most common signs and symptoms in TMD are facial pain during mandibular function and joint crackle/noise. (Bonotto et al., 2016) In this study, significant results were 
found for pain, crackling, stress and NCCL. Depending on the physical activity, the athlete often generates more strength in this region than other daily activities, so dentists should pay extra attention to this disorder. (Bonotto et al., 2016)

Regarding occlusal overload and athletes, two important factors stand out, psychological stress and muscle contraction and teeth clenching during strength exercises. And this can overload the tooth structure, muscle and joint, favoring the onset and progression of NCCL/CDH/GR. (Brandini, Pedrini, et al., 2012; Grippo et al., 2012; PV Soares \& Grippo, 2017; Teixeira et al., 2018; West et al., 2013) Despite this, there was no positive correlation between clenching teeth and the lesions studied. It is necessary to emphasize that as the data collection was done through a questionnaire, we were always depending on the individual's memory bias. Many times, the athlete may have parafunctional habits, but as it has become a habit, he no longer even realizes that he is doing it, such as clenching his teeth. Therefore, it is important for the dentist not to just keep the athlete's report, but look for clinical signs to confirm the habit.

The regression results found a positive relationship between NCCL and orthodontic appliances. This can be explained by the excessive forces that the teeth were subjected to during successive years and caused structural losses of enamel and alveolar bone. (Medeiros et al., 2020; PV Soares \& Grippo, 2017) In recent decades there has been an increase in users of orthodontic devices and it is known that orthodontic treatment can induce tension in the cervical region of teeth, and when the tooth already has NCCL this tension is greater. (CSA et al., 2017; Henrique \& Spini, n.d.; PV Soares \& Grippo, 2017) Therefore, it is necessary to previously warn patients who are going to use orthodontics for possible sequelae of treatment (NCCL, CDH, GR). In addition, when indicated, composite resin restoration promotes better stress distribution similar to a healthy tooth.(CSA et al., 2017; Medeiros et al., 2020; PV et al., 2015)

Brushing alone causes little damage to the tooth structure throughout life. The loss of enamel or dentin can be enhanced if brushing is performed with excessive force and if it is performed after ingestion of acidic foods or/and beverages. (Hong et al., 2020; Wiegand et al., 2007) The significant multivariate regression analysis associated with the prevalence of NCCLs/CDH/GR with excessive brushing force. This makes it necessary for athletes to reorient themselves to prevent tooth structure loss.

Gingival recession is the apical migration of the gingival margin, resulting in root surface exposure.(Kassab \& Cohen, 2003) GR affects a significant proportion of individuals (Rios et al., 2014), and there is no consensus in the literature regarding the etiology of GR. However, it is believed to be multifactorial, and may be due to anatomical, pathological, and physiological factors.(Dörfer et al., 2016; Löe et al., 1992) The prevalence of GR increases with age, (Kassab \& Cohen, 2003; Seong et al., 2018) probably due to the increased life expectancy and also because of improved oral health leading to a decrease in the loss of teeth.(Seong et al., 2018; PV Soares \& Grippo, 2017) In this study, a significant positive relationship was found between GR and age. Among the athletes, there was an increase in the prevalence of GR among those between the ages of 17 and 21 years and those between the ages of 22 and 28 years. However, the prevalence of GR was low in the group of athletes who were more than 28 years old, probably due to the small number of individuals in this group.

\section{Implications for health and performance}

Making accurate diagnosis of NCCL/CDH/GR is of fundamental importance. Failure to identify etiological factors leads to inadequate treatment, failures of restorative treatments, and increased clinical complaints.(Que et al., 2013; PV Soares \& Grippo, 2017) Therefore, it is necessary to create protocols for oral health care based on the needs of athletes to help identify and manage possible risk factors in order to improve the oral health of sportsman.(Broad \& Rye, n.d.; Grippo et al., 2012; PV Soares \& Grippo, 2017) The study on the prevalence of NCCL, CDH and GR in athletes provides relevant information on the condition of their oral health and lifestyle. Despite the limitations, it should be noted that this is the first study in athletes that evaluated NCCL/CDH/GR. More research is needed to assess differences between genders, age groups, other variables and 
also other sports, observing their particularities. This is a first step for other studies to be carried out, especially longitudinal clinical studies. Therefore, it is possible to have a better scientific basis to understand the relationship of this alterations with athletes.

\section{Conclusion}

The prevalence of NCCL, CDH, and GR was $17.42 \%, 35.25 \%$, and 59.09\%, respectively. The most important risk factor for NCCL was age, income, type of sport, training hours, pain and cracking in the TMJ, stress, gridding, excessive brushing force, wear facet and orthodontic appliance; for $\mathrm{CDH}$ were age, type of sport, training hours, acid diet, pain in the TMJ, excessive brushing force, and dental absence; and for GR were age, income, type of sport, training hours, pain in the TMJ, excessive brushing force and dental absence.

Athletes should have particular attention to these alterations. The evaluation of the NCCL / CDH / GR must be part of the clinical routine of the dentist responsible for the athletes, as their lifestyle is closely related to etiological factors and further clinical research is needed.

\section{Acknowledgments}

The authors would like to thank CAPES (Higher Education Personnel Improvement Coordination) for providing the scholarship. Thank you to all dentists, technicians and staff of clubs and participating institutions for facilitating this work and for all the suggestions you have provided.

\section{References}

Alcântara, P. M., Barroso, N. F. F., Botelho, A. M., Douglas-de-Oliveira, D. W., Gonçalves, P. F., \& Flecha, O. D. (2018). Associated factors to cervical dentin hypersensitivity in adults: a transversal study. BMC Oral Health, 18(1), 155. https://doi.org/10.1186/s12903-018-0616-1

Antunes, L. S., Veiga, L., Nery, V. S., Nery, C. C., \& Antunes, L. A. (2017). Sports drink consumption and dental erosion among amateur runners. Journal of Oral Science, 59(4), 639-643. https://doi.org/10.2334/josnusd.16-0611

Bader, J. D., McClure, F., Scurria, M. S., Shugars, D. A., \& Heymann, H. O. (1996). Case-control study of non-carious cervical lesions. Community Dentistry and Oral Epidemiology, 24(4), 286-291. http://www.ncbi.nlm.nih.gov/pubmed/8871039

Bartlett, D. W., \& Shah, P. (2006). A critical review of non-carious cervical (wear) lesions and the role of abfraction, erosion, and abrasion. Journal of Dental Research, 85(4), 306-312. https://doi.org/10.1177/154405910608500405

Bonotto, D., Namba, E. L., Veiga, D. M., Wandembruck, F., Mussi, F., Afonso Cunali, P., Ribeiro Rosa, E. A., \& Azevedo-Alanis, L. R. (2016). Professional karate-do and mixed martial arts fighters present with a high prevalence of temporomandibular disorders. Dental Traumatology, 32(4), 281-285. https://doi.org/10.1111/edt.12238

Borcic, J., Anic, I., Smojver, I., Catic, A., Miletic, I., \& Ribaric, S. P. (2005). 3D finite element model and cervical lesion formation in normal occlusion and in malocclusion. Journal of Oral Rehabilitation, 32(7), 504-510. https://doi.org/10.1111/j.1365-2842.2005.01455.x

Borcic, J., Anic, I., Urek, M. M., \& Ferreri, S. (2004). The prevalence of non-carious cervical lesions in permanent dentition. Journal of Oral Rehabilitation, 31(2), 117-123. http://www.ncbi.nlm.nih.gov/pubmed/15009594

Brandini, D. A., Pedrini, D., Panzarini, S. R., Benete, I. M., \& Trevisan, C. L. (2012). Clinical evaluation of the association of noncarious cervical lesions, parafunctional habits, and TMD diagnosis. Quintessence International (Berlin, Germany: 1985), 43(3), 255-262. http://www.ncbi.nlm.nih.gov/pubmed/22299126

Brandini, D. A., Trevisan, C. L., Panzarini, S. R., \& Pedrini, D. (2012). Clinical evaluation of the association between noncarious cervical lesions and occlusal forces. The Journal of Prosthetic Dentistry, 108(5), 298-303. https://doi.org/10.1016/S0022-3913(12)60180-2

Broad, E. M., \& Rye, L. A. (n.d.). Do current sports nutrition guidelines conflict with good oral health? General Dentistry, 63(6), 18-23. Retrieved May 30, 2019, from http://www.ncbi.nlm.nih.gov/pubmed/26545270

Bryant, S., McLaughlin, K., Morgaine, K., \& Drummond, B. (2011). Elite Athletes and Oral Health. International Journal of Sports Medicine, 32(09), 720724. https://doi.org/10.1055/s-0031-1277192

Canadian Advisory Board on Dentin Hypersensitivity. (2003). Consensus-based recommendations for the diagnosis and management of dentin hypersensitivity. Journal (Canadian Dental Association), 69(4), 221-226. http://www.ncbi.nlm.nih.gov/pubmed/12662460 
CSA, M., AC, M., PG, S., IO, C., AM, G., \& PV, S. (2017). Analysis of hypersensitivity in teeth subjected to orthodontic movement - A pilot clinical study. Clinica - International Journal of Brazilian Dentistry, 13, 238.

DG, G. (2017). A New Perspective on Dentine Hypersensitivity - Guidelines for General Dental Practice. Dental Update, 44(1), 33-42. https://doi.org/10.12968/DENU.2017.44.1.33

Dörfer, C. E., Staehle, H. J., \& Wolff, D. (2016). Three-year randomized study of manual and power toothbrush effects on pre-existing gingival recession. Journal of Clinical Periodontology, 43(6), 512-519. https://doi.org/10.1111/jcpe.12518

F, M., H, O., \& SM, S. (2007). Nutrition for the young athlete. Journal of Sports Sciences, 25 Suppl 1(SUPPL. 1), 73-82. https://doi.org/10.1080/02640410701607338

Favaro Zeola, L., Soares, P. V., \& Cunha-Cruz, J. (2019). Prevalence of dentin hypersensitivity: Systematic review and meta-analysis. Journal of Dentistry, 81, 1-6. https://doi.org/10.1016/j.jdent.2018.12.015

Frese, C., Frese, F., Kuhlmann, S., Saure, D., Reljic, D., Staehle, H. J., \& Wolff, D. (2015). Effect of endurance training on dental erosion, caries, and saliva. Scandinavian Journal of Medicine \& Science in Sports, 25(3), e319-26. https://doi.org/10.1111/sms.12266

Gallagher, J., Ashley, P., Petrie, A., \& Needleman, I. (2018). Oral health and performance impacts in elite and professional athletes. Community Dentistry and Oral Epidemiology, 46(6), 563-568. https://doi.org/10.1111/cdoe.12392

Galvão, A. da M., Zeola, L. F., Moura, G. F., Teixeira, D. N. R., Gonzaga, R. C. de Q., da Silva, G. R., \& Soares, P. V. (2019). A long-term evaluation of experimental potassium oxalate concentrations on dentin hypersensitivity reduction: A triple-blind randomized clinical trial. Journal of Dentistry, 89. https://doi.org/10.1016/j.jdent.2019.103180

Grippo, J. O., Simring, M., \& Coleman, T. A. (2012). Abfraction, abrasion, biocorrosion, and the enigma of noncarious cervical lesions: a 20-year perspective. Journal of Esthetic and Restorative Dentistry: Official Publication of the American Academy of Esthetic Dentistry ... [et Al.], 24(1), 10-23. https://doi.org/10.1111/j.1708-8240.2011.00487.x

Henrique, P., \& Spini, R. (n.d.). EFEITO DE MOVIMENTOS ORTODÔNTICOS NO COMPORTAMENTO BIOMECÂNICO DE PRÉ-MOLARES COM LESÕES CERVICAIS NÃO CARIOSAS. Tese de mestrado. 2016

Hong, D. wei, Lin, X. jiao, Wiegand, A., \& Yu, H. (2020). Does delayed toothbrushing after the consumption of erosive foodstuffs or beverages decrease erosive tooth wear? A systematic review and meta-analysis. In Clinical Oral Investigations. Springer Science and Business Media Deutschland GmbH. https://doi.org/10.1007/s00784-020-03614-9

Kassab, M. M., \& Cohen, R. E. (2003). The etiology and prevalence of gingival recession. Journal of the American Dental Association (1939), 134(2), 220225. http://www.ncbi.nlm.nih.gov/pubmed/12636127

LF, Z., DNR, T., ADM, G., PG, S., \& PV, S. (2020). Brazilian dentists' perception of dentin hypersensitivity management. Brazilian Oral Research, 33. https://doi.org/10.1590/1807-3107BOR-2019.VOL33.0115

Löe, H., Anerud, A., \& Boysen, H. (1992). The natural history of periodontal disease in man: prevalence, severity, and extent of gingival recession. Journal of Periodontology, 63(6), 489-495. https://doi.org/10.1902/jop.1992.63.6.489

Mathew, T., Casamassimo, P. S., \& Hayes, J. R. (2002). Relationship between sports drinks and dental erosion in 304 university athletes in Columbus, Ohio, USA. Caries Research, 36(4), 281-287. https://doi.org/10.1159/000063927

Medeiros, T. L. M., Mutran, S. C. A. N., Espinosa, D. G., do Carmo Freitas Faial, K., Pinheiro, H. H. C., \& D’Almeida Couto, R. S. (2020). Prevalence and risk indicators of non-carious cervical lesions in male footballers. BMC Oral Health, 20(1), 215. https://doi.org/10.1186/s12903-020-01200-9

Moazzez, R., Smith, B. G. N., \& Bartlett, D. W. (2000). Oral pH and drinking habit during ingestion of a carbonated drink in a group of adolescents with dental erosion. Journal of Dentistry, 28(6), 395-397. https://doi.org/10.1016/S0300-5712(00)00020-8

Mulic, A., Tveit, A. B., Songe, D., Sivertsen, H., \& Skaare, A. B. (2012). Dental erosive wear and salivary flow rate in physically active young adults. BMC Oral Health, 12(1). https://doi.org/10.1186/1472-6831-12-8

Nascimento, M. E. da S., Júnior, J. R. L. dos S., Lima, M. V. A., Almeida, N. M. S. de, Hora, S. L., \& Cabral, L. L. (2020). Etiologia e tratamento da hipersensibilidade dentinária na atualidade: revisão integrativa. Research, Society and Development, 9(8), e661986192. https://doi.org/10.33448/rsd-v9i8.6192

Needleman, I, Ashley, P., Petrie, A., Fortune, F., Turner, W., Jones, J., Niggli, J., Engebretsen, L., Budgett, R., Donos, N., Clough, T., \& Porter, S. (2013). Oral health and impact on performance of athletes participating in the London 2012 Olympic Games: a cross-sectional study. British Journal of Sports Medicine, 47(16), 1054-1058. https://doi.org/10.1136/bjsports-2013-092891

Needleman, Ian, Ashley, P., Meehan, L., Petrie, A., Weiler, R., McNally, S., Ayer, C., Hanna, R., Hunt, I., Kell, S., Ridgewell, P., \& Taylor, R. (2016). Poor oral health including active caries in 187 UK professional male football players: clinical dental examination performed by dentists. British Journal of Sports Medicine, 50(1), 41-44. https://doi.org/10.1136/bjsports-2015-094953

PV, S., AC, M., LF, Z., PG, S., AM, G., TC, M., AG, P., BR, R., TA, C., \& JO, G. (2015). Loading and composite restoration as sessment of various noncarious cervical lesions morphologies - 3D finite element analysis. Australian Dental Journal, 60(3), 309-316. https://doi.org/10.1111/ADJ.12233

Que, K., Guo, B., Jia, Z., Chen, Z., Yang, J., \& Gao, P. (2013). A cross-sectional study: non-carious cervical lesions, cervical dentine hypersensitivity and related risk factors. Journal of Oral Rehabilitation, 4O(1), 24-32. https://doi.org/10.1111/j.1365-2842.2012.02342.x

Rios, F. S., Costa, R. S. A., Moura, M. S., Jardim, J. J., Maltz, M., \& Haas, A. N. (2014). Estimates and multivariable risk assessment of gingival recession in the population of adults from Porto Alegre, Brazil. Journal of Clinical Periodontology, 41(11), 1098-1107. https://doi.org/10.1111/jcpe.12303 
Rogerson, D. (2017). Vegan diets: Practical advice for athletes and exercisers. In Journal of the International Society of Sports Nutrition (Vol. 14, Issue 1). BioMed Central Ltd. https://doi.org/10.1186/s12970-017-0192-9

Seong, J., Bartlett, D., Newcombe, R. G., Claydon, N. C. A., Hellin, N., \& West, N. X. (2018). Prevalence of gingival recession and study of associated related factors in young UK adults. Journal of Dentistry, 76, 58-67. https://doi.org/10.1016/j.jdent.2018.06.005

Silva, M. S., Lima, A. N. de A. N., Pereira, M. M. A., Ferraz Mendes, R., \& Prado Júnior, R. R. (2019). Prevalence and predictive factors of dentin hypersensitivity in Brazilian adolescents. Journal of Clinical Periodontology, 46(4), 448-456. https://doi.org/10.1111/jcpe.13097

Sirimaharaj, V., Brearley Messer, L., \& Morgan, M. V. (2002). Acidic diet and dental erosion among athletes. Australian Dental Journal, 47(3), 228-236. http://www.ncbi.nlm.nih.gov/pubmed/12405463

Soares, P. V., Tolentino, A. B., Machado, A. C., Dias, R. B., \& Coto, N. P. (2014). Sports dentistry: a perspective for the future. Revista Brasileira de Educação Física e Esporte, 28(2), 351-358. https://doi.org/10.1590/1807-55092014000200351

Soares, PV, \& Grippo, J. (2017). Noncarious Cervical Lesions and Cervical Dentin Hypersensitivity: Etiology, Diagnosis, and Treatment.

Soares, P V, Souza, L. V, Veríssimo, C., Zeola, L. F., Pereira, A. G., Santos-Filho, P. C. F., \& Fernandes-Neto, A. J. (2014). Effect of root morphology on biomechanical behaviour of premolars associated with abfraction lesions and different loading types. Journal of Oral Rehabilitation, 41(2), 108-114. https://doi.org/10.1111/joor.12113

Souza, L. A. de, Elmadjian, T. R., Brito e Dias, R., \& Coto, N. P. (n.d.). Prevalence of malocclusions in the 13-20-year-old categories of football athletes. Brazilian Oral Research, 25(1), 19-22. Retrieved May 30, 2019, from http://www.ncbi.nlm.nih.gov/pubmed/21359447

Tanabe, M., Takahashi, T., Shimoyama, K., Toyoshima, Y., \& Ueno, T. (2013). Effects of rehydration and food consumption on salivary flow, pH and buffering capacity in young adult volunteers during ergometer exercise. Journal of the International Society of Sports Nutrition, 10. https://doi.org/10.1186/1550-2783-10-49

Teixeira, D. N. R., Thomas, R. Z., Soares, P. V., Cune, M. S., Gresnigt, M. M. M., \& Slot, D. E. (2020). Prevalence of noncarious cervical lesions among adults: A systematic review. In Journal of Dentistry (Vol. 95). Elsevier Ltd. https://doi.org/10.1016/j.jdent.2020.103285

Teixeira, D. N. R., Zeola, L. F., Machado, A. C., Gomes, R. R., Souza, P. G., Mendes, D. C., \& Soares, P. V. (2018). Relationship between noncarious cervical lesions, cervical dentin hypersensitivity, gingival recession, and associated risk factors: A cross-sectional study. Journal of Dentistry, 76, 93-97. https://doi.org/10.1016/j.jdent.2018.06.017

WANG, Y., QUE, K., LIN, L., HU, D., \& LI, X. (2012). The prevalence of dentine hypersensitivity in the general population in China. Journal of Oral Rehabilitation, 39(11), 812-820. https://doi.org/10.1111/j.1365-2842.2012.02334.x

West, N. X., Sanz, M., Lussi, A., Bartlett, D., Bouchard, P., \& Bourgeois, D. (2013). Prevalence of dentine hypersensitivity and study of associated factors: A European population-based cross-sectional study. Journal of Dentistry, 41(10), 841-851. https://doi.org/10.1016/j.jdent.2013.07.017

Wiegand, A., Köwing, L., \& Attin, T. (2007). Impact of brushing force on abrasion of acid-softened and sound enamel. Archives of Oral Biology, 52(11), 1043-1047. https://doi.org/10.1016/j.archoralbio.2007.06.004

Yang, J., Cai, D., Wang, F., He, D., Ma, L., Jin, Y., \& Que, K. (2016). Non-carious cervical lesions (NCCLs) in a random sampling community population and the association of NCCLs with occlusive wear. Journal of Oral Rehabilitation, 43(12), 960-966. https://doi.org/10.1111/joor.12445

Yoshizaki, K. T., Francisconi-Dos-Rios, L. F., Sobral, M. A. P., Aranha, A. C. C., Mendes, F. M., \& Scaramucci, T. (2017). Clinical features and factors associated with non-carious cervical lesions and dentin hypersensitivity. Journal of Oral Rehabilitation, 44(2), 112-118. https://doi.org/10.1111/joor.12469

Zuza, A., Racic, M., Ivkovic, N., Krunic, J., Stojanovic, N., Bozovic, D., Bankovic-Lazarevic, D., \& Vujaskovic, M. (2019). Prevalence of non-carious cervical lesions among the general population of the Republic of Srpska, Bosnia and Herzegovina. International Dental Journal, idj.12462. https://doi.org/10.1111/idj.12462 